
\title{
AdindaMas
}

Volume 1 Nomor 2, Januari 2022

DOI: https://doi.org/10.37726/adindamas.v1i2.321

\section{Pendampingan Pembelajaran Al-Qur'an Bagi Para Pedagang Pasar Pengkolan Pasawahan Kidul Kec. Pasawahan Kab. Purwakarta}

\author{
Asep Dede Kurnia ${ }^{1}$, Jalaludin ${ }^{2}$, Diana Novita ${ }^{3}$ \\ ${ }^{1}$ Sekolah Tinggi Iilmu Ekonomi Syariah (STIES) Indonesia Purwakarta \\ 1asepdedekurnia@gmail.com \\ 2jalaludinstiesip@gmail.com \\ ${ }^{3}$ Mahasiswa Sekolah Tinggi Iilmu Ekonomi Syariah (STIES) Indonesia Purwakarta \\ 3diananovita@gmail.com
}

\begin{abstract}
ABSTRAK
Berdasarkan hasil observasi sementara ditemukan banyak pedagang Pengkolan Pasawahan Kidul yang membaca al-Qur'an masih terbata-bata, alasannya beragam, ada beralasan karena sibuk dengan bisnis berdagang mereka masing-masing, sehingga tidak menyempatkan waktu untuk membaca al-Qur'an. Alasan berikutnya karena memang dari kecil tidak lancar baca al-Qur'an, karena orang tuanya tidak perhatian terhadap pendidikan al-Qur'an, hingga terbawa sampai tua saat ini. Hasil pengabdian kepada masyarakat dengan tema Pendampingan Pembelajaran AlQur'an Bagi Pada Pedagang Pasar Pengkolan Pasawahan Purwakarta melalui beberapa metode dan pendekatan. Bagi para pedagang yang masih buta huruf arab (hijaiyah), tim PKM menggunakan metode Baghdadiyah, yakni metode ini disebut juga dengan metode "eja". Bagi para pedagang yang masih terbata-bata tim PKM menggunkan metode iqra, yakni membaca Alquran tanpa dieja, langsung dibaca dengan harakat, diharapkan dengan sering dipraktekan walaupun masih terbata-bata akan semakin lancar. Tidak hanya itu, Tim PKM menggunakan metode tilawati bagi para pedagang yang sudah lumayan lancar membaca al-Qur'an, diharapkan pengenalan metode ini bisa menambah fasihat bacaan al-Qur'an para pedagang Pasar Pengkolan Pasawahan Purwakarta. Selanjutnya bagi para pedagang Pasar Pengkolan Pasawahan Purwakarta yang sudah lancar dalam bacaan al-Qur'an, tim PKM
\end{abstract}


meminta bantuannya untuk menjadi tutor dalam sistem "bandungan" bagi para pedagang yang belum lancar bacaan al-Qur'annya.

Kata kunci - Pendampingan Pembelajaran Al-Qur'an, Pembelajaran Al-Qur'an, Para Pedagang Pasar.

\section{ABSTRACT}

Based on the results of temporary observations, it was found that many Pengkolan Pasawahan Kidul traders who read the Qur'an were still haltingly, the reasons were various, there was a reason that they were busy with their respective trading businesses, so they did not take the time to read the Qur'an. The next reason is because from a young age he was not fluent in reading the Qur'an, because his parents did not pay attention to the education of the Qur'an, until he was carried away until now. The results of community service with the theme of Al-Qur'an Learning Assistance for Traders at the Pasar Pengkolan Pasawahan Purwakarta through several methods and approaches. For traders who are still illiterate in Arabic (hijaiyah), the PKM team uses the Baghdadiyah method, which is also known as the "spelling" method. For traders who are still stammering, the PKM team uses the iqra method, namely reading the Koran without spelling it, reading it directly with the pronunciation, it is hoped that it will be practiced often even though it is still halting it will get smoother. Not only that, the PKM team uses the tilawati method for traders who are already quite fluent in reading the Qur'an, it is hoped that the introduction of this method can add to the advice of reading the Qur'an for traders at Pengkolan Market, Pasawahan Purwakarta. Furthermore, for traders at Pasar Pengkolan Pasawahan Purwakarta who are already fluent in reading the Qur'an, the PKM team asked for their help to become tutors in the "bandungan" system for traders who were not fluent in reading the Qur'an.

Keywords - Al-Qur'an Learning Assistance, Al-Qur'an Learning, Market Traders.

\section{PENDAHULUAN}

Pasar Pengkolan merupakan salah satu pasar tradisional minimalis yang ada di lingkungan desa Pasawahan Kidul Kec. Pasawahan Kab. Purwakarta. Purwakarta yang dikenal sebagai kota tasbih dan kota santri yang masih teguh melestarikan budaya dan tradisi, termasuk spiritual keagamaan yang masih kental. Selain menjadi kewajiban sholat lima waktu adalah sebagai rutinitas kebiasaan masyarakat Purwakarta. Tahlilan, yasinan, dan ritual-ritual lainnya mewarnai desa Pasawahan Kidul itu. Pasar bukan hanya tempat transaksi untuk mendapatkan sesuatu yang kita inginkan, melainkan pasar juga sebagai jalan untuk mendapatkan kebahagiaan dunia dan akhirat. Kebahagiaan dunia dan akhirat bisa digapai dengan cara mentaati semua perintah Allah SWT. dan Menjauhi segala larangan Allah SWT.

Salah satu bentuk perintah Allah SWT. atau ibadah adalah membaca al-Qur'an, sering kita temukan karena saking terlalu sibuknya mengejar pundi-pundi rupiah,

ADINDAMAS (Jurnal Pengabdian Kepada Masyarakat), Volume 1, Nomor 1, Januari 2022 http://journal.sties-purwakarta.ac.id/index.php/adindamas/ ISSN: 2798-2874 (Media Online) 2798-4702 (Media Cetak) 
lupa diri kita akan hakikat Pencipta pundi-pundi rupiah tersebut. Hal ini dikarenakan kita jarang Taqarrub Ilallah salah satunya jarang membaca al-Qur'an, hingga bacaan kita yang dulunya lancar bacaan al-Qur'an kita, menjadi terbata-bata karena tidak sering atau istiqomah dalam membaca al-Qur'annya.

Syekhul Islam Muhyiddin Abu Zakariyya Yahya bin Syaraf An-Nawawi dalam kitabnya, Riyaadhus-Shaalihiin, membuat bab khusus tentang Keutamaan Membaca Al-Qur'an, di antaranya:

Pertama, Al-Qur'an akan menjadi syafaat atau penolong di hari kiamat untuk para pembacanya. ${ }^{1}$

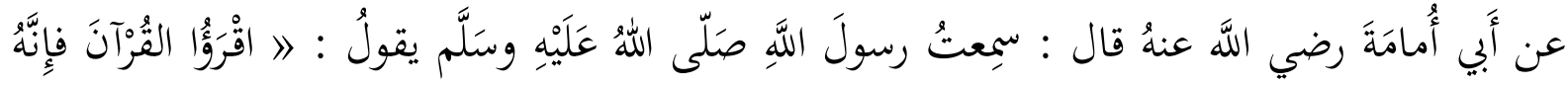

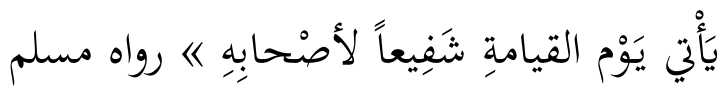

Dari Abu Amamah ra, aku mendengar Rasulullah saw. bersabda, "Bacalah Al-Qur'an, karena sesungguhnya ia akan menjadi syafaat bagi para pembacanya di hari kiamat." (HR. Muslim);

Kedua, orang yang mempelajari dan mengajarkan Al-Qur'an merupakan sebaik-

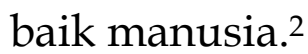

$$
\begin{aligned}
& \text { عن عثمانَ بن عفانَ رضيَ اللَّه عنهُ قال : قالَ رسولُ اللَّهِ صَلّى اللهُ عَلَيْهِه وسَتَّمَ : 》 خَيركُم مَنْ تَعَلَّمَ }
\end{aligned}
$$

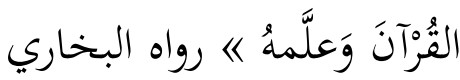

Dari Usman bin Affan ra, Rasulullah saw. bersabda, "Sebaik-baik kalian adalah yang mempelajari al-Qur'an dan mengajarkannya." (HR. Tirmidzi);

Ketiga, untuk orang-orang yang mahir membaca Al-Qur'an, maka kelak ia akan bersama para malaikat-Nya; ${ }^{3}$

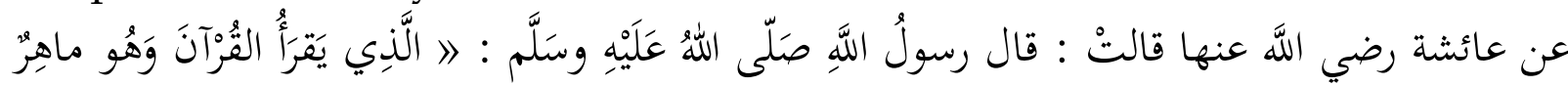

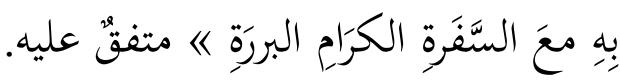

Dari Aisyah ra, berkata; bahwa Rasulullah saw. bersabda, "Orang yang membaca AlQur'an dan ia mahir membacanya, maka kelak ia akan bersama para malaikat yang mulia lagi taat kepada Allah." (HR. Bukhari Muslim);

${ }^{1}$ Ahmad Rosidi, “Motivasi Santri Dalam Menghafal Al-Qur'an (Studi Multi Kasus Di Pondok Pesantren Ilmu Al-Qur'an (PPIQ) PP. Nurul Jadid Paiton Probolinggo, Dan Pondok Pesantren Tahfizhul Al-Qur'an Raudhatusshalihin Wetan Pasar Besar Malang)," Al-Qodiri: Jurnal Pendidikan Sosial dan Keagamaan 10, no. 1 (2016): 67-101.

${ }^{2}$ Muzakkir Muzakkir, “Keutamaan Belajar Dan Mengajarkan Al-Qur'an: Metode Maudhu'i Dalam Perspektif Hadis," Lentera Pendidikan: Jurnal Ilmu Tarbiyah dan Keguruan 18, no. 1 (June 27, 2015): 107-121, http://journal.uin-alauddin.ac.id/index.php/lentera_pendidikan/article/view/684.

${ }^{3}$ Rosidi, “Motivasi Santri Dalam Menghafal Al-Qur'an (Studi Multi Kasus Di Pondok Pesantren Ilmu AlQur'an (PPIQ) PP. Nurul Jadid Paiton Probolinggo, Dan Pondok Pesantren Tahfizhul Al-Qur'an Raudhatusshalihin Wetan Pasar Besar Malang)."

ADINDAMAS (Jurnal Pengabdian Kepada Masyarakat), Volume 1, Nomor 1, Januari 2022 http://journal.sties-purwakarta.ac.id/index.php/adindamas/ ISSN: 2798-2874 (Media Online) 2798-4702 (Media Cetak) 
Keempat, untuk mereka yang belum lancar dalam membaca dan mengkhatamkan Al-Qur'an, tidak boleh bersedih, sebab Allah tetap berikan dua pahala. ${ }^{4}$

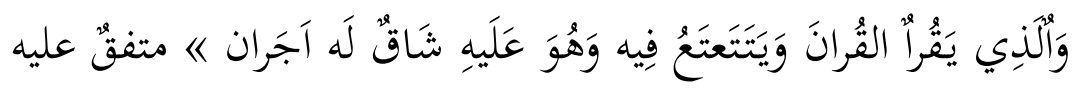

Rasulullah bersabda, "Dan orang yang membaca Al-Qur'an, sedang ia masih terbatabata lagi berat dalam membacanya, maka ia akan mendapatkan dua pahala." (HR. Bukhari Muslim);

Kelima, Al-Qur'an dapat meningkatkan derajat kita di mata Allah. ${ }^{5}$

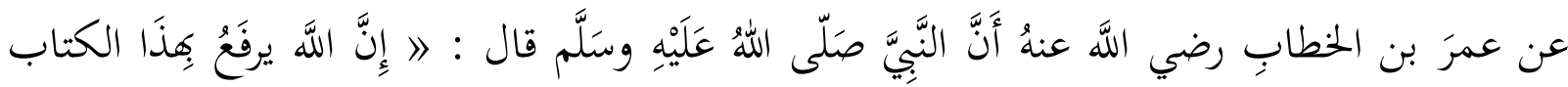

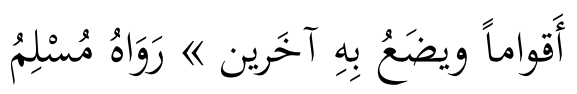

Dari Umar bin Khatab ra. Rasulullah saw. bersabda,: "Sesungguhnya Allah SWT. akan mengangkat derajat suatu kaum dengan kitab ini (Al-Qur'an), dengan dengannya pula Allah akan merendahkan kaum yang lain." (HR. Muslim);6

Dalam literatur hadis lain, dijelaskan juga tentang keutamaan membaca AlQur'an. Antara lain, bahwa Allah akan menurunkan ketenangan, rahmat dan memuji suatu kaum yang melantunkan ayat-ayat Al-Qur'an, serta malaikat akan melingkarinya. ${ }^{7}$

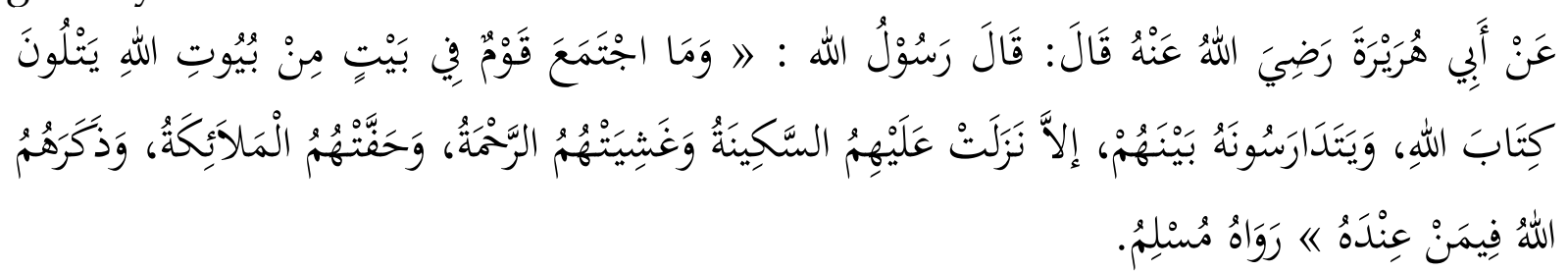

Dari Abu Hurairah RA, ia berkata: "Rasulullah SAW. bersabda, "Tidaklah suatu kaum berkumpul dalam salah satu rumah dari rumah-rumah Allah (masjid), untuk membaca Al-Qur'an dan mempelajarinya, kecuali akan diturunkan kepada mereka ketenangan, dan mereka dilingkupi rahmat Allah, para malaikat akan mengelilingi mereka dan Allah akan menyebut-nyebut mereka di hadapan makhluk-Nya yang berada didekat-Nya (para malaikat)." (HR. Muslim) ${ }^{8}$

${ }^{4}$ M. Jamhuri M. Jamhuri, “Penggunaan Metode Drill Dalam Meningkatkan Kemampuan Membaca AlQur'an Siswa Di SMK Dewantoro Purwosari," Al-Murabbi 1, no. 2 (2016): 201-215. Hadis."

${ }^{5}$ Muzakkir, "Keutamaan Belajar Dan Mengajarkan Al-Qur'an: Metode Maudhu'i Dalam Perspektif

${ }^{6}$ Rosniati Hakim, "Pembentukan Karakter Peserta Didik Melalui Pendidikan Berbasis Al-Quran," Jurnal Pendidikan Karakter 2, no. 2 (2014): 123-136.

7 Ibid.

8 Jamhuri, “Penggunaan Metode Drill Dalam Meningkatkan Kemampuan Membaca Al-Qur'an Siswa Di SMK Dewantoro Purwosari."

ADINDAMAS (Jurnal Pengabdian Kepada Masyarakat), Volume 1, Nomor 1, Januari 2022 http://journal.sties-purwakarta.ac.id/index.php/adindamas/

ISSN: 2798-2874 (Media Online) 2798-4702 (Media Cetak) 
Selain itu, mengkhatamkan Al-Qur'an adalah amal yang paling dicintai Allah. Dalam hadis riwayat Imam Tirmidzi dijelaskan:

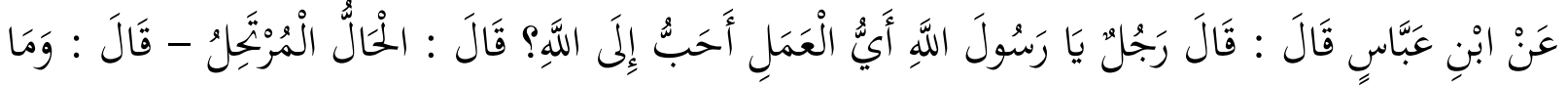

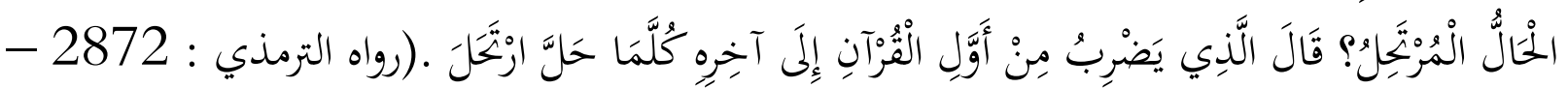

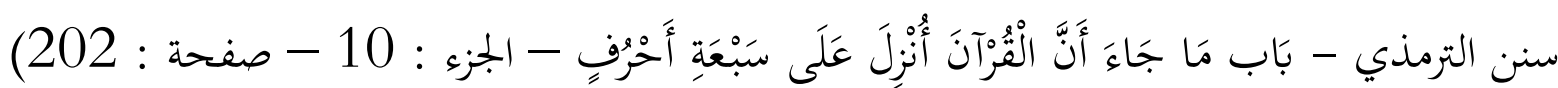

Dari Ibnu Abbas ra, beliau mengatakan ada seseorang yang bertanya kepada Rasulullah saw., "Wahai Rasulullah, amalan apakah yang paling dicintai Allah?" Beliau menjawab, "Al-hal wal murtahal." Orang ini bertanya lagi, "Apa itu al-hal wal murtahal, wahai Rasulullah?" Beliau menjawab, "Yaitu yang membaca Al-Qur'an dari awal hingga akhir. Setiap kali selesai ia mengulanginya lagi dari awal." (HR. Tirmidzi:2872, Sunan Tirmidzi, Bab maa jaa-a annal-Qur'an unzila 'alaa sab'ati ahruf, juz 10, hal.202) ${ }^{9}$

Berdasarkan hasil observasi sementara ditemukan banyak pedagang Pengkolan Pasawahan Kidul yang membaca al-Qur'an masih terbata-bata, alasannya beragam, ada beralasan karena sibuk dengan bisnis berdagang mereka masing-masing, sehingga tidak menyempatkan waktu untuk membaca al-Qur'an. Alasan berikutnya karena memang dari kecil tidak lancar baca al-Qur'an, karena orang tuanya tidak perhatian terhadap pendidikan al-Qur'an, hingga terbawa sampai tua saat ini.

Berdasarkan hasil observasi diatas, fokus pendampingan pada mitra Pengabdian Kepada Masyarakat lebih kepada tata cara pelafalan huruf hijaiyyah yang nantinya dipraktekan dalam membaca al-Qur'an secara baik dan benar. Merujuk dari apa yang telah diungkapkan, maka kegiatan pengabdian kepada masyarakat (PKM) ini sebagai suatu kegiatan pendampingan yang melibatkan para pedagang yang menjadi Mitra PKM dan kesemuanya berlokasi di Pasar Pengkolan Pasawahan Kidul Purwakarta. Akhirnya melalui kegiatan PKM ini diharapkan dapat memberi manfaat bagi mitra PKM sebagai salah satu alternatif dalam melancarkan bacaan al-Qur'an dan sebagai salah satu sarana mendekatkan diri (taqarruban Ilallah) kepada Allah SWT.

\section{METODE}

\section{A. Tempat dan Waktu}

Kegiatan pengabdian kepada masyarakat dengan judul Pendampingan Pembelajaran Al-Qur'an Bagi Pada Pedagang Pasar Pengkolan Pasawahan Purwakarta dilaksanakan pada tanggal 2-10 Februari 2018, bertempat di masjid Pasar Pengkolan Pasawahan Kidul Kec. Pasawahan Kab. Purwakarta. Hadis."

9 Muzakkir, “Keutamaan Belajar Dan Mengajarkan Al-Qur'an: Metode Maudhu'i Dalam Perspektif

ADINDAMAS (Jurnal Pengabdian Kepada Masyarakat), Volume 1, Nomor 1, Januari 2022 http://journal.sties-purwakarta.ac.id/index.php/adindamas/ ISSN: 2798-2874 (Media Online) 2798-4702 (Media Cetak) 


\section{B. Ruang Lingkup dan Objek Pengabdian}

Objek yang menjadi sasaran dari kegiatan pengabdian kepada masyarakat ini adalah para pedagang Pasar Pengkolan Pasawahan Kidul Kec. Pasawahan Kab. Purwakarta. Tim PkM mengidentifikasi masalah sesuai dengan rencana kegiatan sebagai berikut ;

1. Banyaknya bacaan al-Qur' an para Pedagang yang masih terbata-bata;

2. Kurangnya edukasi tentang pentingnya baca al-Qur'an;

3. Kurangnya edukasi korelasi al-Qur'an dengan berdagang atau pencarian rezeki.

\section{Pendekatan Atau Teknik Pengabdian}

Kegiatan pengabdian kepada masyarakat ini dilakukan dengan menggunakan pendekatan service learning, dengan melalui tiga tahapan, yakni tahapan persiapan, tahapan analisis, dan tahapan refleksi. Analisis Kebutuhan Analisis ini meliputi analisis kondisi pedagang dan pemetaan kondisi Pasar Pengkolan Pasawahan Kidul tempat para pedagang berada. Tahapan berikutnya adalah tahapan refleksi yakni Penyusunan program, Pelaksanaan program, Pendampingan dan Publikasi, Evaluasi program, Monitoring, dan Pembuatan laporan

\section{HASIL DAN PEMBAHASAN}

\section{A.Persiapan Program}

Sebelum program pendampingan dimulai, tahap awal adalah melakukan persiapan matang terkait pelaksanaan dan evaluasi program yang akan berjalan. Pada tahap ini pengabdi melakukan rapat internal bersama team. Rapat internal itu memutuskan pelaksanaan kegiatan pengabdian berikut ini:

a. Program pengabdian dilaksanakan selama 1 minggu, yaitu mulai tanggal 2 10 Februari 2018.

b. Pelaksanaan program pengabdian dilaksanakan setelah shalat maghrib hingga pukul 20.00 WIB.

c. Metode pembelajaran menggunakan pendekatan metode pedagogi dan andragogi.

\section{B. Implementasi Program}

Langkah selanjutnya adalah implementasi program pengabdian. Amalan membaca al-Qur'an merupakan suatu keperluan dan juga tanggung jawab bagi invidual seorang muslim dan juga dituntut untuk mahir membaca al-Qur'an, apalagi memahami dan mengamalkannya. Maka dari itu, bukan saja isi al-Qur'an yang 
menjadi panduan hidup manusia, malah membaca juga dapat menenangkan jiwa dan dinilai ibadah.

Kepentingan mempelajari serta mengajarkan al-Qur'an suatu yang tidak dapat kita elakkan lagi karena al-Qur'an merupakan sumber asas dalam pembinaan manusia. Selanjutnya Mohd Ali dan Haron Din menyebutkan membaca al-Qur'an adalah ibadah yang diberi pahala oleh Allah kepada pembacanya jika dibaca dengan benar serta mengikuti kaedah bacaan dan hukum tajwid. hal ini selaras jika kita merujuk kepada hadist Rasul SAW. :

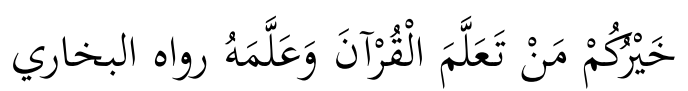

"Sebaik-baik kalian adalah yang mempelajari Al-Qur'an dan mengajarkannya." [AlBukhari 5027]

Sejarah kegiatan belajar dan mengajar al-Qur'an dimulai dari pelantikan Muhammad menjadi Rasul, tepatnya di gua Hiro', malaikat Jibril memandu Nabi untuk membaca 5 ayat awal dari surah al-'Alaq, Jibril memulai dengan membaca yang kemudian ditirukan oleh Rasul SAW yang sering kali kita menyebutnya dengan istilah Talaqqi.

Metode talaqqi (pengajaran bertatap muka) juga dipakai oleh Rosulullah dalam mengajarkan al-Qur'an dan keilmuan lain kepada para sahabat dan metode talaqqi juga masih terus berlanjut sampai era modern ini. Metode pembelajaran al-Qur'an dewasa ini sering kita jumpai melalui banyak pendekatan seperti belajar al-Qur'an 3 jam, belajar al-Qur'an cepat dan lain sebagainya, yang juga kebanyakan dari beberapa metode tersebut masih fokus pada kecepatan bukan ketepatan. Alangkah baiknya ada metode yang menggabungkan keduanya yang selain cepat juga tepat. Dalam program pengabdian kali ini akan mencoba menggali metode yang cepat dan tepat melalui beberapa prinsip pembelajaran al-Qur'an bagi para pedagang di Pasar Pengkolan Pasawahan Kidul Kec. Pasawahan Kab. Purwakarta.

Proses pembelajaran al-Qur'an bagi para pedagang di Pasar Pengkolan Pasawahan Kidul Kec. Pasawahan Kab. Purwakarta tim PKM menggunakan beberapa metode seperti pedagogi dan andragogi. Karena peserta yang ikut berpartisipasi ternyata bukan hanya orangtua saja melainkan dari kalangan anakanak pedagang ikut berpartisipasi juga. Secara literal pedagogi berati seni dan ilmu pengetahuan tentang mendidik anak-anak dan sering digunakan sebagai sebuah sinonim untuk suatu pengajaran. Secara lebih tepatnya, pedagogi mewujudkan pendidikan yang berfokuskan guru. Pedagogi bertujuan agar anak di kemudian hari mampu memahami dan menjalani kehidupan dan kelak dapat menghidupi diri 
mereka sendiri, dapat hidup secara bermakna, dan dapat turut memuliakan kehidupan.

\section{Gambar 3.1}

Pembelajaran Al-Qur'an Bagi Anak-Anak Pedagang Pasar Pengkolan Pasawahan Kidul Purwakarta
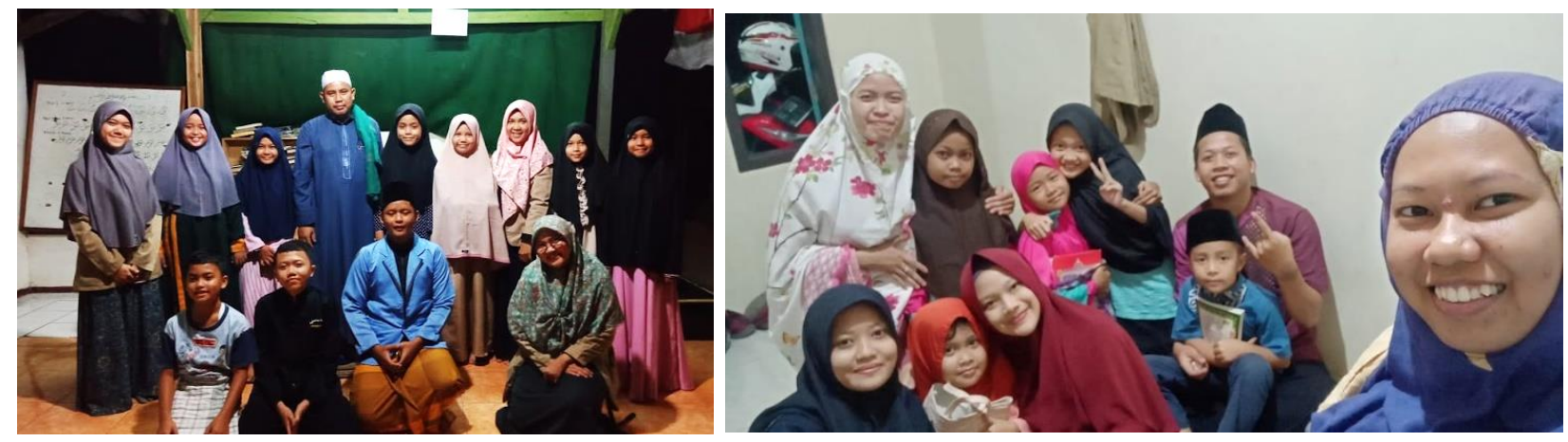

Dalam model pedagogi, guru memiliki tanggung jawab penuh untuk membuat keputusan tentang apa yang akan dipelajari, bagaimana akan dipelajari, ketika akan dipelajari, dan jika materi telah dipelajari. Pedagogi, atau instruksi guru diarahkan seperti yang umumnya dikenal, tempat siswa dalam peran tunduk membutuhkan ketaatan dengan instruksi guru. Hal ini didasarkan pada asumsi bahwa peserta didik hanya perlu mengetahui apa guru mengajarkan mereka. Hasilnya adalah situasi pengajaran dan pembelajaran yang aktif mempromosikan ketergantungan pada instruktur.

Berikutnya proses pembelajaran al-Qur'an menggunakan metode andragogi, andragogi berasal dari dua kata dalam bahasa Yunani, yakni Andra berarti orang dewasa dan agogos berarti memimpin. Pendefinisian andragogi kemudian dirumuskan sebagai "Suatu seni dan ilmu untuk membantu orang dewasa belajar".

Asumsi andragogi sebagai berikut :

1. Orang dewasa perlu dibina untuk mengalami perubahan dari kebergantungan kepada pengajar kepada kemandirian dalam belajar. Orang dewasa mampu mengarahkan dirinya mempelajari sesuai kebutuhannya.

2. Pengalaman orang dewasa dapat dijadikan sebagai sumber di dalam kegiatan belajar untuk memperkaya dirinya dan sesamanya.

3. Kesiapan belajar orang dewasa bertumbuh dan berkembang terkait dengan tugas, tanggung jawab dan masalah kehidupannya.

4. Orientasi belajar orang dewasa harus diarahkan dari berpusat pada bahan pengajaran kepada pemecahan-pemecahan masalah.

5. Motivasi belajar orang dewasa harus diarahkan dari pemberian pujian dan hukuman kepada dorongan dari dalam diri sendiri serta karena rasa ingin tahu.

ADINDAMAS (Jurnal Pengabdian Kepada Masyarakat), Volume 1, Nomor 1, Januari 2022 http://journal.sties-purwakarta.ac.id/index.php/adindamas/ ISSN: 2798-2874 (Media Online) 2798-4702 (Media Cetak) 


\section{Gambar 3.2}

Proses Edukasi Pembelajaran Al-Qur'an Bagi Para Pedagang Pasar Pengkolan Pasawahan Kidul Purwakarta
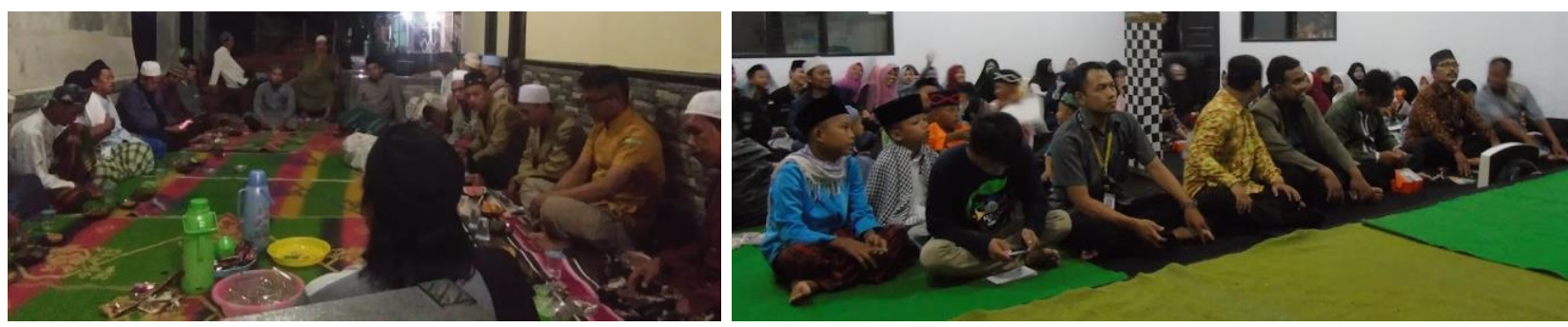

Dalam proses pengajaran terdiri dari beberapa komponen yang tidak bisa dipisahkan diantaranya adalah metode pengajaran. Metode mengajar adalah suatu teknik penyampaian bahan pelajaran kepada anak didik. Ia dimaksudkan agar anak didik dapat menangkap pelajaran dengan mudah, efektif dan dapat dicerna oleh anak dengan baik.

Menurut Horald B. Allen dan Russel method is a set of a certain procedures or techniques assembled in accordance with the principle of a certain approach to earning teaching and used in conjunction with a certain syllabus and materials. ${ }^{10}$ Sementara Zakiah Dradjat menyatakan bahwa metode hanyalah prosedur yang akan diikuti. 11 Dari dua penjelasan pengertian metode tersebut dapat diketahui bahwa yang dimaksud metode adalah serangkaian cara yang digunakan dalam pemberian materi kepada anak didik. ${ }^{12}$

Guru harus mempergunakan banyak metode pada waktu mengajar. Variasi metode mengakibatkan penyajian bahan pelajaran lebih menarik perhatian siswa, mudah diterima anak didik, dan kelas menjadi hidup karena metode penyajian yang selalu sama akan membosankan anak didik.

Dalam aktivitas belajar mengajar, metode yang diterapkan guru sangat berperan dalam rangka mengan- tarkan anak kepada pemahaman serta penguasaan atas materi pengajaran yang disajikan oleh guru. Pemilihan dan penggunaan metode dalam mengajar yang tepat akan mampu menumbuhkan dan membangkitkan minat serta perhatian terhadap materi pelajaran yang disajikan, sehingga anak-anak tidak bosan mengikutinya.

Berbagai macam metode mengajar yang telah dikemukakan oleh para ahli tidak cocok untuk digunakan terhadap berbagai mata pelajaran, misalnya dalam

${ }^{10}$ Horald B Allen and Russel N Camp Bell, Teaching English As Second Language (New Delhi: Tata moc Grow Hill Publishing Company LTD, 1978).

11 Zakiah Dradjat, Metodologi Pengajaran Agama Islam, 1st ed. (Jakarta: Bumi Aksara, 1996).

12 Rusdiah Rusdiah, "Konsep Metode Pembelajaran Alquran," Tarbiyah Islamiyah: Jurnal Ilmiah Pendidikan Agama Islam 2, no. 1 (2012): 1-25.

ADINDAMAS (Jurnal Pengabdian Kepada Masyarakat), Volume 1, Nomor 1, Januari 2022 http://journal.sties-purwakarta.ac.id/index.php/adindamas/

ISSN: 2798-2874 (Media Online) 2798-4702 (Media Cetak) 
pendidikan Alquran (baca tulis Alquran) harus pandai memilih metode mana yang tepat digunakan pada mata pelajaran tersebut. Ada beberapa metode pembelajaran Alquran yang dapat diterapkan oleh guru mata pelajaran yaitu: ${ }^{13}$

\section{Metode Dirosa}

Dirosa merupakan sistem pembinaan Islam berkelanjutan yang diawali dengan belajar baca Alquran. Panduan baca Alquran pada Dirosa disusun tahun 2006 yang dikembangkan Wahdah Islamiyah Gowa. Panduan ini khusus orang dewasa dengan sistem klasikal 20 kali pertemuan. Buku panduan ini lahir dari sebuah proses yang panjang, dari sebuah perjalanan pengajaran Alquran di kalangan ibu-ibu yang dialami sendiri oleh pencetus dan penulis buku ini. Telah terjadi proses pencarian format yang terbaik pada pengajaran Alquran di kalangan ibu-ibu selama kurang lebih 15 tahun dengan berganti-ganti metode. Dan akhirnya ditemukanlah satu format yang sementara dianggap paling ideal, paling baik dan efektif yaitu memadukan pembelajaran baca Alquran dengan pengenalan dasar-dasar keislaman. Buku panduan belajar baca Alqurannya disusun tahun 2006. Sedangkan buku-buku penunjangnya yang dipakai pada santri TK-TP Alquran. Panduan dirosa sudah mulai berkembang di daerah-daerah, baik Sulawesi, Kalimantan maupun beberapa daerah kepulauan Maluku; yang dibawa oleh para da'i. Secara garis besar metode pengajarannya adalah baca-tunjuk-simak-ulang, yaitu pembina membacakan, peserta menunjuk tulisan, men- dengarkan dengan seksama kemudian mengulangi bacaan tadi. Tehnik ini dilakukan bukan hanya bagi bacaan pembina, tetapi juga bacaan dari sesama peserta. Semakin banyak mendengar dan mengulang, semakin besar kemungkinan untuk bisa baca Alquran lebih cepat.

\section{Metode Baghdadiyah}

Metode ini disebut juga dengan metode "eja" berasal dari bahasa Baghdad pada masa pemerintahan khalifah Bani Abbasiyah. Tidak tahu dengan pasti siapa penyusunnya. Selanjutnya setelah seabad lebih berkembang secara merata di tanah air. Secara didaktik materi-materinya diurutkan dari yang konkrit ke abstrak, dari yang mudah ke yang sukar, dan dari yang umum sifatnya kepada materi yang terperinci (khusus).

Secara garis besar, qaidah bagdadiyah memerlukan 17 langkah. 30 huruf hijaiyah selalu ditampilkan secara utuh dalam tipe langkah. Seolah-olah sejumlah huruf tersebut menjadi tema sentral dengan berbagai variasi. Variasi dari tiap-tiap

13 Danny Abrianto, Hasrian Rudi Setiawan, and Ahmad Fuadi, “Implementasi Kurikulum 2013 Pada Mata Pelajaran Alquran Hadits Di MTs. Swasta Teladan Gebang Kab. Langkat," Intiqad: Jurnal Agama dan Pendidikan Islam 10, no. 2 (December 30, 2018): http://jurnal.umsu.ac.id/index.php/intiqad/article/view/2490.

ADINDAMAS (Jurnal Pengabdian Kepada Masyarakat), Volume 1, Nomor 1, Januari 2022 http://journal.sties-purwakarta.ac.id/index.php/adindamas/ ISSN: 2798-2874 (Media Online) 2798-4702 (Media Cetak) 
langkah menimbulkan rasa estetika bagi siswa (enak didengar) karena bunyinya bersajak berirama. Indah dilihat karena penulisan huruf yang sama. Metode ini diajarkan secara klasikal maupun privat. Kelebihan qaidah bagdhadiyah antara lain:

a. Bahan materi pelajaran disusun secara sekunsif;

b. 30 huruf abjad hampir selalu ditampilkan pada setiap langkah secara utuh sebagai tema sentral;

c. Pola bunyi dan susunan huruf (wazan) disusun secara rapi;

d. Keterampilan mengeja yang dikembangkan merupakan daya tarik tersendiri; dan

e. Materi tajwid secara mendasar terintegrasi dalam setiap langkah.

Kekurangan metode ini adalah:

a. Qaidah baghdadiyah yang asli sulit diketahui, karena sudah mengalami beberapa modifikasi kecil;

b. Penyajian materi terkesan menjemukan; dan

c. Penampilan beberapa huruf yang mirip dapat menyulitkan pengalaman siswa.

\section{Metode Iqra}

Metode iqro' disusun Bapak As'ad Humam dari Kotagede Yogyakarta muncul, sekitar tahun 1988 dan dikembangkan oleh AMM (Angkatan Muda Masjid dan Musholla) Yogyakarta dengan membuka TK Alquran dan TP Alquran. Metode iqro semakin berkembang dan menyebar merata di Indonesia setelah munas DPP BKPMI di Surabaya yang menjadikan TK Alquran dan metode iqro sebagai sebagai program utama perjuangannya. Metode Iqro' terdiri dari 6 jilid dengan variasi warna cover yang memikat perhatian anak TK Alquran.

Penggunaan metode iqra yang dimaksud adalah membaca Alquran tanpa dieja, langsung dibaca dengan harakat, materi pelajaran disesuaikan dengan kurikulum pendidikan. ${ }^{14}$ Kelebihan dari metode ini adalah anak setelah belajar dengan metode Iqro dapat lebih cepat membaca lafadz-perlafadz, lalu ayat per ayat. Bentuk-bentuk pengajaran dengan metode iqro' antara lain:
a. TK Alquran;
b. TP Alquran;
c. Digunakan pada pengajian anak-anak di masjid/ musholla;
d. Menjadi materi dalam kursus baca tulis Alquran;
e. Menjadi program ekstra kurikuler sekolah; dan
f. Digunakan di majelis-majelis taklim.

14 Asad Humam, Buku Iqra Cara Cepat Belajar Membaca Alquran (Yogyakarta: Balai Litbang LPTQ Nasioanal, 2000).

ADINDAMAS (Jurnal Pengabdian Kepada Masyarakat), Volume 1, Nomor 1, Januari 2022 http://journal.sties-purwakarta.ac.id/index.php/adindamas/ ISSN: 2798-2874 (Media Online) 2798-4702 (Media Cetak) 


\section{Metode Tilawati}

Metode tilawati disusun pada tahun 2002 oleh Tim terdiri dari Hasan Sadzili, Ali Muaffa dkk. Kemudian dikembangkan Pesantren Virtual Nurul Falah Surabaya. Metode tilawati dikembangkan untuk menjawab permasalahan yang berkembang di TK/TPA, antara lain:

a. Mutu pendidikan dan kualitas santri lulusan TK/TP Alquran belum sesuai dengan target;

b. Metode pembelajaran masih belum menciptakan suasana belajar yang kondosif, sehingga proses belajar tidak efektif;

c. Tidak adanya keseimbangan pendanaan antara pemasukan dan pengeluaran; dan

d. Waktu pendidikan masih terlalu lama sehingga banyak santri drop out sebelum khatam quran.

Kelas TQA pasca TPA, TQA belum bisa terlaksana bagi santri-santrinya, antara lain:

a. Santri mampu membaca Alquran dengan tartil;

b. Santri mampu membenarkan bacaan Alquran yang salah; dan

c. Ketuntasan belajar santri secara individu $70 \%$ dan secara kelompok $80 \%$.

d. Prinsip-prinsip metode ini adalah

e. Disampaikan dengan praktis;

f. Menggunakan lagu Rost; dan

g. Menggunakan pendekatan klasikal dan individu secara seimbang.

\section{Metode Sintesis}

Metode sintesis merupakan salah satu metode dalam pembelajaran baca tulis Alquran yang dimulai dengan mengenalkan bunyi-bunyi huruf hijaiyah kemudian dirang- kai menjadi kata dan kalimat. Metode sintesis ini banyak digunakan lembagalembaga pendidikan dalam pembelajaran baca tulis Alquran di seluruh Indonesia. Di samping itu, guru menggunakan dua sistem pengajaran dalam kegiatan belajar mengajar, yaitu sistem individual (privat) dan sistem klasikal. Sedangkan dalam pembelajaran menulis huruf Alquran guru menggunakan langkah yang berbedabeda, yaitu menulis dengan cara menyalin, menulis dengan dikte (imla'), dan menulis dengan panduan. Kelebihan metode imla dari metode yang lain adalah:

a. Untuk memperoleh kecakapan motoris, seperti menulis, melafalkan huruf, kata-kata atau kalimat, membuat alat-alat, menggunakan alat-alat (mesin, permainan dan atletik), dan terampil menggunakan peralatan olah raga; dan 
b. Untuk memperoleh kecakapan mental seperti dalam perkalian, menjumlah pengurangan, pembagian, tanda-tanda (symbol).

Adapun kekurangan adalah:

a. Sering hasil catatan sangat buruk, sehingga suit dibaca dan dipelajari; dan

b. Peserta didik pasif menerima dan tidak bisa mengajukan pertanyaan tentang ha-hal yang kurang jelas.

\section{Metode Albarqy}

Metode ini dapat dinilai sebagai metode cepat membaca Alquran yang paling awal. Metode ini ditemukan dosen fakultas Adab IAIN Sunan Ampel Surabaya. Muhadjir Sulthon pada tahun 1965. Awalnya al-Barqy diperuntukkan bagi siswa SD Islam Tarbiyah, Surabaya. Siswa yang belajar metode ini lebih cepat mampu membaca Alquran. Muhadjir lantas membukukan metodenya pada tahun 1978. Dengan judul Cara Cepat Mempelajari Bacaan Alquran al-Barqy. metode anti lupa karena mempunyai struktur yang apabila pada saat siswa lupa dengan hurufhuruf/suku kata yang telah dipelajari, maka ia akan dengan mudah dapat mengingat kembali tanpa bantuan guru. Penyebutan anti lupa itu sendiri adalah hasil penelitian yang dilakukan oleh Deperteman Agama RI.

Metode ini diperuntukkan bagi siapa saja mulai anak- anak hingga orang dewasa. Metode ini mempunyai keunggulan anak-anak hingga orang dewasa. Metode ini mempunyai keunggulan yaitu anak tidak akan lupa sehingga secara langsung dapat mempermudah dan mempercepat anak/siswa belajara membaca. Waktu untuk belajar memba-ca Alquran menjadi semakin singkat. Keuntungan yang didapat;

a. Bagi guru, mempunayai keahlian tambahan sehingga dapat mengajar dengan lebih baik, bisa menambah penghasilan diwaktu luang dengan keahlian yang dipelajari;

b. Bagi murid, cepat belajar sehingga tidak merasa bosan dan menambah kepercayaan dirinya karena sudah bisa belajar dan menguasainya dalam waktu singkat, hanya satu level sehingga biayanya lebih murah; dan

c. Bagi sekolah, menjadi lebih terkenal karena murid- muridnya mempunyai kemampuan untuk menguasai pelajaran lebih cepat dibandingkan dengan sekolah lain.

Langkah-langkah penggunaan metode Al-Barqy sebagai berikut:

a. Langkah pertama

Guru meminta siswa untuk menghafalkan terlebih dahulu beberapa kata lembaga dalam metode Al-Barqy. Kata lembaga tersebut merupakan struktur yang terdiri dari huruf- huruf hijaiyah. 
Contohnya:

ADA RAJA - MAHA KAYA - KATA WANA - SAMA LABA.

Guru membacakan kata lembaga tersebut kemudian diikuti oleh peserta didik.

b. Langkah kedua

Setelah peserta didik sudah mampu menghafalkan kata kunci tersebut, kemudian guru menuliskannya di papan tulis. Contohnya :

$$
\text { اد ر ج م ح ك ي ك ت و ن س مل ب }
$$

Selanjutnya guru meminta siswa untuk membacakan huruf-huruf tersebut, karena sebelumnya peserta didik sudah menghafalkan kata lembaga, maka huruf-huruf hijaiyah yang dituliskan guru mampu dibaca peserta didik.

c. Langkah ketiga

Guru meminta siswa untuk menuliskan kata-kata kunci tersebut dengan huruf hijaiyah. Sebagai permulaan guru meminta siswa mengikuti contoh tulisan huruf tersebut. Selanjutnya guru menyebutkan salah satu huruf dengan acak dan siswa menuliskannya di buku dengan cara guru mendikte dan siswa menulis sambil menyebutkan huruf yang ditulisnya berulang kali sampai hafal.

d. Langkah keempat

Guru meminta siswa satu persatu untuk membaca huruf-huruf tersebut dengan cara guru menunjukan huruf- huruf tersebut dengan tidak teratur. Contohnya :

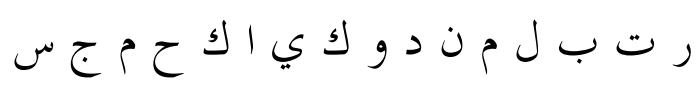

\section{Metode Ummi}

Metode Ummi adalah suatu sistem yang terdiri dari 3 komponen sistem: Buku Praktis Metode Ummi, Manajemen Mutu Metode Ummi, dan Guru Bersertifikat Metode Ummi. Ketiganya harus digunakan secara simultan jika ingin mendapatkan hasil yang optimal dari metode ini. Metode Ummi lahir diilhami dari metode-metode pengajaran membaca Alquran yang sudah tersebar di masyarakat, khususnya dari metode yang telah sukses mengantarkan banyak anak bisa membaca Al Quran dengan tartil.

\section{Metode Qiraati}

Metode ini ditemukan KH. Dachlan Salim Zarkasyi (wafat 2001 M) dari Semarang, Jawa Tengah. Metode yang disebarkan sejak awal tahun 1970an ini 
memungkinkan anak-anak mempelajari Alquran secara cepat dan mudah. Kiai Dachlan yang mulai mengajar Alquran pada 1963 merasa metode membaca yang ada belum memadai. Misalnya metode qaidah baghdadiyah dari Baghdad Irak yang dianggap metode tertua, terlalu mengandalkan hafalan dan tidak mengenalkan cara baca tartil (jelas dan tepat). Kia Dachlan kemudian menerbitkan enam jilid buku pelajaran membaca Alquran untuk TK Alquran anak usia 4-6 tahun pada 1 Juli 1986.

Usai merampungkan penyusunannya. KH. Dachlan berwasiat supaya tidak sembarang orang mengajarkan metode qiraati, tapi semua orang boleh diajar dengan metode qiraati. Dalam perkembangannya sasaran metode qiraati kian diperluas. Kini ada qiraati untuk anak usia 4-6 tahun, 6-12 tahun dan untuk mahasiswa. Secara umum metode pengajaran qirati adalalah: 15

a. Klasikal dan privat;

b. Guru menjelaskan dengan memberi contoh materi pokok bahasan, selanjutnya siswa membaca sendiri;

c. Siswa membaca tanpa mengeja; dan

d. Sejak awal belajar siswa ditekankan untuk membaca dengan tepat dan cepat.

Dari penjelasan beberapa metode di atas, dapat diketahui bahwa dalam mengajarkan pendidikan Alquran (baca tulis Alquran) tidak cukup hanya menggunakan satu metode, karena setiap metode pasti mempunyai kelebihan dan kekurangan, sebagaimana yang kita ketahui bahwa para ahli pendidikan selalu berusaha untuk memperbaiki kekurangan-kekurangan metode yang ada dengan mencari dan menemukan metode-metode yang baru agar tujuan dari pendidikan Alquran (baca tulis Alquran) dapat tercapai dengan baik. Di samping keterampilan guru dalam menerapkan metode pengajaran, guru juga dituntut untuk terampil dalam menyampaikan materi kepada siswa dengan baik agar nantinya dari penjelasan yang diberikan oleh guru tersebut tidak membuat siswa bingung.

\section{KESIMPULAN}

Pengabdian kepada masyarakat dengan tema Pendampingan Pembelajaran AlQur'an Bagi Pada Pedagang Pasar Pengkolan Pasawahan Purwakarta melalui beberapa metode dan pendekatan. Bagi para pedagang yang masih buta huruf arab (hijaiyah), tim PKM menggunakan metode Baghdadiyah, yakni metode ini disebut juga dengan metode "eja". Bagi para pedagang yang masih terbata-bata tim PKM menggunkan metode iqra, yakni membaca Alquran tanpa dieja, langsung dibaca dengan harakat, diharapkan dengan sering dipraktekan walaupun masih terbata-bata

${ }^{15}$ Khoirul Budi Utomo, "Strategi Dan Metode Pembelajaran Pendidikan Agama Islam MI," Modeling: Jurnal Program Studi PGMI 5, no. 2 (2018): 145-156.

ADINDAMAS (Jurnal Pengabdian Kepada Masyarakat), Volume 1, Nomor 1, Januari 2022 http://journal.sties-purwakarta.ac.id/index.php/adindamas/

ISSN: 2798-2874 (Media Online) 2798-4702 (Media Cetak) 
akan semakin lancar. Tidak hanya itu, Tim PKM menggunakan metode tilawati bagi para pedagang yang sudah lumayan lancar membaca al-Qur'an, diharapkan pengenalan metode ini bisa menambah fasihat bacaan al-Qur' an para pedagang Pasar Pengkolan Pasawahan Purwakarta. Selanjutnya bagi para pedagang Pasar Pengkolan Pasawahan Purwakarta yang sudah lancar dalam bacaan al-Qur'an, tim PKM meminta bantuannya untuk menjadi tutor dalam sistem "bandungan" bagi para pedagang yang belum lancar bacaan al-Qur'annya.

\section{DAFTAR PUSTAKA}

Abrianto, Danny, Hasrian Rudi Setiawan, and Ahmad Fuadi. "Implementasi Kurikulum 2013 Pada Mata Pelajaran Alquran Hadits Di MTs. Swasta Teladan Gebang Kab. Langkat." Intigad: Jurnal Agama dan Pendidikan Islam 10, no. 2 (December 30, 2018):

283-298.

http://jurnal.umsu.ac.id/index.php/intiqad/article/view/2490.

Allen, Horald B, and Russel N Camp Bell. Teaching English As Second Language. New Delhi: Tata moc Grow Hill Publishing Company LTD, 1978.

Dradjat, Zakiah. Metodologi Pengajaran Agama Islam. 1st ed. Jakarta: Bumi Aksara, 1996. Hakim, Rosniati. "Pembentukan Karakter Peserta Didik Melalui Pendidikan Berbasis Al-Quran." Jurnal Pendidikan Karakter 2, no. 2 (2014): 123-136.

Humam, Asad. Buku Iqra Cara Cepat Belajar Membaca Alquran. Yogyakarta: Balai Litbang LPTQ Nasioanal, 2000.

Jamhuri, M. Jamhuri M. “Penggunaan Metode Drill Dalam Meningkatkan Kemampuan Membaca Al-Qur'an Siswa Di SMK Dewantoro Purwosari." AlMurabbi 1, no. 2 (2016): 201-215.

Muzakkir, Muzakkir. “Keutamaan Belajar Dan Mengajarkan Al-Qur'an: Metode Maudhu'i Dalam Perspektif Hadis." Lentera Pendidikan : Jurnal Ilmu Tarbiyah dan Keguruan 18, no. 1 (June 27, 2015): 107-121. http://journal.uinalauddin.ac.id/index.php/lentera_pendidikan/article/view/684.

Rosidi, Ahmad. “Motivasi Santri Dalam Menghafal Al-Qur'an (Studi Multi Kasus Di Pondok Pesantren Ilmu Al-Qur'an (PPIQ) PP. Nurul Jadid Paiton Probolinggo, Dan Pondok Pesantren Tahfizhul Al-Qur'an Raudhatusshalihin Wetan Pasar Besar Malang)." Al-Qodiri: Jurnal Pendidikan Sosial dan Keagamaan 10, no. 1 (2016): 67-101.

Rusdiah, Rusdiah. "Konsep Metode Pembelajaran Alquran." Tarbiyah Islamiyah: Jurnal Ilmiah Pendidikan Agama Islam 2, no. 1 (2012): 1-25.

Utomo, Khoirul Budi. "Strategi Dan Metode Pembelajaran Pendidikan Agama Islam MI." Modeling : Jurnal Program Studi PGMI 5, no. 2 (2018): 145-156. 